$14^{\text {th }}$ Conf. Agric. Develop. Res., Fac. of Agric., Ain Shams Univ., March, 2019, Cairo, Egypt

Special Issue, 27(1), 913 - 923, 2019

Website: http://strategy-plan.asu.edu.eg/AUJASCI/

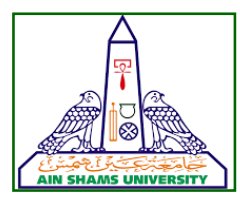

\title{
EVALUATE THE EFFECT OF SOME FACTORS AFFECTING SOLUBILIZATION OF PHOSPHORUS IN RHIZOSPHERE
}

\author{
Rookaya S. Elhag ${ }^{*}$ Elgala, A.M., Elsharawy M.A.O. and Eid, M.A.
}

Soil Sci. Dept., Fac. of Agric., Ain Shams Univ., P.O. Box 68, Hadayek Shubra 11241, Cairo, Egypt

\author{
${ }^{*}$ Corresponding author: rookaia_salah@agr.asu.edu.eg
}

Received 1 October, 2018, Accepted 9 October, 2018

\begin{abstract}
The aim of this work was to conduct pot experiment to study the ability of plant roots on solubilizing various sources of phosphorus and factors that may facilitate or inhibit their activity. A split medium - split root technique experiment was conducted to study the effect of $\mathrm{CaCO}_{3}, \mathrm{pH}$, organic matter (humic acid) and bentonite on the $\mathrm{pH}, \mathrm{P}$ solubility in the medium and $\mathrm{P}$ concentration in bean plants (Vicia faba var. balady). The changes in $\mathrm{pH}$ of the lower solution was recorded, also the root exudate was collected in $500 \mathrm{ml}$ of $\mathrm{CaCl}_{2}$ solution $0.5 \times 10^{-4}$ $M$ and $\mathrm{pH}$ 6.85. Results showed that the highest recorded total dry weight was found when both $\mathrm{N}$ forms were applied in the ratio of $1: 4 \mathrm{NO}_{3}^{-}: \mathrm{NH}^{+}{ }_{4}$ or $\mathrm{NO}_{3}^{-}$alone. The mechanism of solubilizing rock phosphate by exudating protons or organic, amino and other organic compounds is possible at the root surface even in alkaline soil as long as the rock phosphate material was added near the root and organic matter was added to limit the fixing power of the inorganic components as $\mathrm{CaCO}_{3}$ and excess soluble $\mathrm{Ca}$. Also, the availability of $\mathrm{P}$ from rock phosphate sources depends on its reactivity value.
\end{abstract}

Keywords: Organic matter; Bentonite; $\mathrm{CaCO}_{3}$; $\mathrm{pH}$; Rock phosphate; Rhizosphere; Split medium technique; Faba bean plants.

\section{INTRODUCTION}

The mobility of phosphorus $(P)$ in the shallow subsurface is a matter of critical importance and considerable complexity. Its importance stems from the fact that $P$ an essential nutrient for all plants and animals life. Agricultural fertilizers and other soil amendments, such as mineral P fertilizers and animal manure, provide $P$ that is readily available to plants. The short-term availability of $P$ to crops is strongly influenced by biochemical processes that affect organic matter, while its longterm status is generally determined by geochemical transformations. Phosphorus is an essential nutrient for plants and is one of the most commonly applied as mineral fertilizer (Jenkins and Jenkins, 2012).

Afif et al (1993) found that at high application rates, $P$ available to plants is negatively correlated to the amount of lime in soil, but not to Fe, clay content, or CEC. In contrast, other studies indicate that $P$ retention increases with the ratio of $\mathrm{Fe}$ oxides to $\mathrm{CaCO}_{3}$ (Carreira and Lajtha,1997) The preponderance of the evidence (Zhou and Li, 2001) suggests that non-carbonate clays provide most of the $\mathrm{P}$ adsorbing surfaces in many calcareous soils, especially at low $P$ concentrations. It has even been reported that a $1.6 \%(\mathrm{w} / \mathrm{w})$ coating of $\mathrm{Fe}_{2} \mathrm{O}_{3}$ on calcite increases the $\mathrm{P}$ sorption capacity 9 -fold (Tunesi et al 1999). As the $P$ content of the soil increases, sorption by carbonates becomes more important. Hopkins and Ellsworth (2005) reported that Calcareous soil is defined as having the presence of significant quantities of free excess lime (calcium or magnesium carbonate). Lime dissolves in neutral to acid soil $\mathrm{pH}$, but does not readily dissolve in alkaline soil and, instead, serves as a sink for surface adsorbed calcium phosphate precipitation. They found that the bioavailability of $\mathrm{P}$ is strongly tied to soil $\mathrm{pH}$. The formation of iron and aluminum phosphate minerals results in the reduced solubility of $P$ in strongly acidic soil, while $\mathrm{P}$ solubility improving as $\mathrm{pH}$ approaches nearly 
neutral. This maximum solubility and plant availability of $\mathrm{P}$ at $\mathrm{pH} 6.5$ declines again as the $\mathrm{pH}$ increases into the alkaline range.

Humic acid is a commercial product of organic fertilizers containing most elements that improve soil fertility and increase nutrients availability, thus enhances plant growth and yield as well as decreases the harmful effect of stresses (Doran et al 2003). The effect of $H A$ on the availability of $P$ and micronutrients has been given particular attention because of observed increases in uptake rates of these nutrients following application of humic acid (Satisha and Devarajan, 2005). Humic acid (HA) from wheat straw leachate can inhibit the formation of insoluble Ca phosphates and thus may enhance $P$ bioavailability (Grossl and Inskeep, 1991).

Robbins et al 1999, has reported that largescale manure applications to a silty clay loam soils results in a linear increase in available $P$, up to a soil dependent limit. Humic and fulvic acids comprise a wide variety of organic materials that are present in all agricultural soils. Their effects on plant growth and nutrition are well documented, (Adani et al 1998) and they can be applied to improve soil structure and increase crop yields. Reports on the influence of humic materials on $P$ retention and release have largely focused on the mineral components of the soils studied. Recent work indicates that the occurrence of $\mathrm{Al}$ and $\mathrm{Fe}$ has a significant effect on the $P$ sorption capacity, despite the presence of large amounts of organic matter (Giesler et al 2005). Earlier, it had been shown that $P$ decreases the sorption of organic $C$ to acid mineral soils, suggesting a ligand exchange process at the surface (Kaiser and Zech, 1997).

As regards the reverse, i.e. the release of $P$ under the influence of dissolved humic materials; (Delgado et al 2002) have published one of the few accounts dealing with this issue. They found that application of humics to the soil increases the recovery of Olsen $P$ in all soils tested, except in those with very high $\mathrm{Na}$ content. Humic acids preparation was reported to increase the uptake of mineral elements (Mackowiak et al 2001), to promote the root length (Cenellas et al 2002), and to increase the fresh and dry weights of crop plants (Chen et al 2004). Due to the positive effect of humic substances on the visible growth of plants. Thus, the aim of this work is to evaluate the effect of some factors such as $\mathrm{CaCO}_{3}, \mathrm{pH}$, bintonite, organic matter (humic acid) on $\mathrm{P}$ solubility in the rhizosphere as well as increasing the efficiency of such nutrient in the studied soils.

\section{MATERIALS AND METHODS}

\section{The materials}

\section{Organic matter}

Organic matter was used as humic acid (HA), potassium humate powder, supplied by Union for Agriculture Development CO. The chemical composition of potassium humate is given in Table 1.

\section{Bentonite and rock phosphate}

A sample was taken from the El-Ahram Mining Company. The crushed original minerals were ground and passed through 125-250 $\mu$ m diameter and were dried in an oven at $100 \pm 5{ }^{\circ} \mathrm{C}$ for $24 \mathrm{~h}$. The results of the some physical and chemical properties are shown in Table 1.

\section{The experiment}

\section{Split Medium Technique experiments}

The combined sand and solution culture technique previously designed and used by (Elgala and Amberger 1988) was used in this investigation, as shown in Fig. 1. The technique was used to study the role of plant roots in mobilizing $P$ from rock phosphates or super phosphates. In this work broad bean plants (Vicia faba var. balady) was used as test plants. Seeds were first germinated between filter papers. After one week, five seedlings were transferred to each of the upper Neubauer pots to which $400 \mathrm{~g}$ of acid washed sand as pure media were placed. The seedlings were irrigated with various composition of a nutrient solution (Elgala and Amberger, 1988). 

in Rhizosphere

Table. 1. Some physical and chemical properties of the used humic acid $(H A)$, bentonite and rock phosphate (RP)

\begin{tabular}{|c|c|c|c|}
\hline Characteristics & Humic acid & Bentonite & Rock phosphate \\
\hline Silt, \% & nd & 30.2 & nd \\
\hline Clay, \% & nd & 57.3 & nd \\
\hline $\mathrm{SP}, \%$ & nd & 78.0 & nd \\
\hline $\mathrm{EC}_{\mathrm{e}}, \mathrm{dS} \cdot \mathrm{m}^{-1}$ & 1.30 & 2.30 & 3.6 \\
\hline $\mathrm{pH}(1: 5)$ & 4.70 & 8.13 & 7.3 \\
\hline $\mathrm{OM}, \%$ & 86.7 & nd & nd \\
\hline OC, $\%$ & 50.2 & nd & nd \\
\hline $\mathrm{CEC}, \mathrm{c} \mathrm{mol} \mathrm{c} / \mathrm{kg}$ & 174 & 83.0 & 4.69 \\
\hline \multicolumn{4}{|c|}{ Soluble ions (soil paste ext.), meq/l } \\
\hline $\mathrm{Ca}^{2+}$ & 1.80 & 12.0 & 30.0 \\
\hline $\mathrm{Mg}^{2+}$ & 1.50 & 4.60 & 5.0 \\
\hline $\mathrm{Na}^{+}$ & 0.70 & 5.00 & 4.57 \\
\hline $\mathrm{K}^{+}$ & 8.20 & 1.27 & 0.29 \\
\hline $\mathrm{Cl}^{-}$ & 3.70 & 5.40 & 1.20 \\
\hline $\mathrm{HCO}_{3}^{-}$ & 2.80 & 3.70 & 20.0 \\
\hline $\mathrm{CO}_{3}{ }^{2-}$ & nd & nd & nd \\
\hline $\mathrm{SO}_{4}^{2-}$ & 6.50 & 13.8 & 18.7 \\
\hline \multicolumn{4}{|c|}{ Chemically available nutrients, $\mu \mathrm{g} / \mathrm{g}$} \\
\hline $\mathrm{N}$ & 7.00 & nd & $\mathrm{nd}^{*}$ \\
\hline $\mathrm{P}$ & 22.0 & 0.20 & 3.42 \\
\hline $\mathrm{K}$ & 210 & 80.0 & nd \\
\hline $\mathrm{Fe}$ & 12.8 & 3.80 & nd \\
\hline $\mathrm{Mn}$ & 10.2 & 12.5 & nd \\
\hline $\mathrm{Zn}$ & 3.00 & 9.40 & nd \\
\hline $\mathrm{Cu}$ & 1.60 & 0.20 & nd \\
\hline \multicolumn{4}{|c|}{ Total macronutrients, \% } \\
\hline $\mathrm{N}$ & 4.80 & nd & 0.50 \\
\hline $\mathrm{P}$ & 0.83 & 0.75 & 8.45 \\
\hline K & 6.00 & 1.80 & 0.02 \\
\hline C:N ratio & 10.4 & nd & nd \\
\hline
\end{tabular}

${ }^{*}$ nd $=$ not detected 


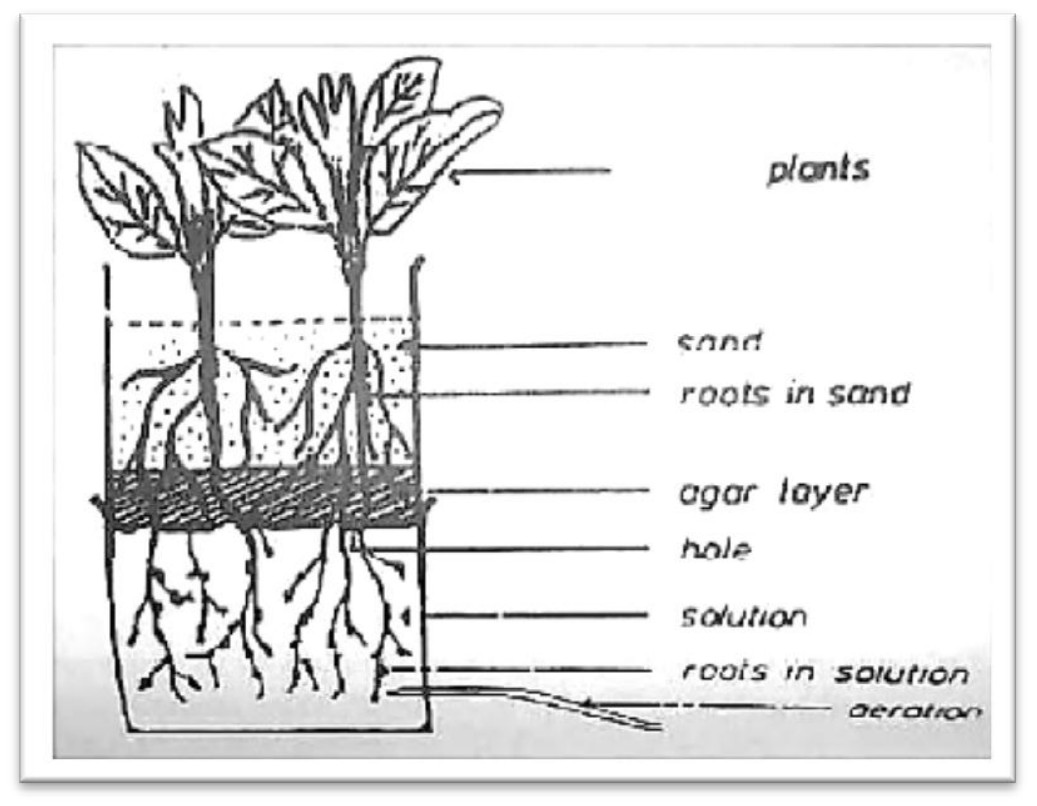

Fig. 1. Split medium technique

As follows: (a) Nutrient solution without $\mathrm{P}$ (modified Hoagland nutrient solution $0.5 \mathrm{M}$ ), (b) Complete nutrient solution with $\mathrm{P}\left(\mathrm{NO}_{3}{ }^{-}: \mathrm{NH}_{4}{ }^{+}\right.$is $\left.1: 4\right)$, (c) Solution $\mathrm{B}$ with $\mathrm{N}$ in the $\mathrm{NH}_{4}{ }^{+}$form, (d) Solution $B$ with $\mathrm{N}$ in the $\mathrm{NO}_{3}{ }^{-}$form.

The $\mathrm{pH}$ of the nutrient solution was adjusted to $\mathrm{pH}$ 5.5. The experiment was conducted in green house, after 15- days from seedling each pot was placed over another one as shown in Fig. 1 and the solution in the lower pot was the same as the irrigation solution of the upper pot. The roots penetrated the agar layer and the root systems grew normally in the lower pots. The changes in $\mathrm{pH}$ of the lower solution was recorded, also the root exudate was collected in $500 \mathrm{ml}$ of $\mathrm{CaCl}_{2}$ solution 0.5 $\times 10^{-4} \mathrm{M}$ and $\mathrm{pH} 6.85$.

After one week from placing, the lower pot containing the $\mathrm{CaCl}_{2}$ solution, the following treatments were applied on the control without $P(-P)$ growing plants:

1. Nutrient solution without $P($ Control $-P)$

2. Complete nutrient solution (Control)

3. Nutrient solution whereas $\mathrm{N}$ form was $\mathrm{NH}_{4}{ }^{+}$ (Hoagland $\left(\mathrm{N}=\mathrm{NH}_{4}{ }^{+}\right)$)

4. Nutrient solution whereas $\mathrm{N}$ forms was $\mathrm{NO}_{3}{ }^{-}$ (Hoagland $\left(\mathrm{N}=\mathrm{NO}_{3}{ }^{-}\right)$)

5. Nutrient solution without $P+1$ g. ${ }^{*} R \cdot P(P=R P)$

6. Nutrient solution without $P+1 \mathrm{~g} .{ }^{*} \mathrm{~S} . \mathrm{P}(\mathrm{P}=\mathrm{SP})$

7. Treatment $\mathrm{No} 5+1 \mathrm{~g} . \mathrm{CaCO}_{3}\left(\mathrm{P}=\mathrm{RP}+\mathrm{CaCO}_{3}\right)$

8. Treatment No $5+1 \mathrm{~g}$. bentonite $\left({ }^{\star} P=R P+\right.$ bentonite)
9. Treatment No $5+1 \mathrm{~g} . \mathrm{H} \cdot \mathrm{A}(\mathrm{P}=\mathrm{RP}+\mathrm{HA})$

10. Treatment No $5+1 \mathrm{~g}$. bentonite $+1 \mathrm{~g}$. $\mathrm{H} . \mathrm{A}(\mathrm{P}=\mathrm{RP}+$ bentonite $+\mathrm{HA})$

11. Treatment No $6+1 \mathrm{~g} . \mathrm{CaCO}_{3}\left(\mathrm{P}=\mathrm{SP}+\mathrm{CaCO}_{3}\right)$

12. Treatment No $6+1 \mathrm{~g}$. bentonite $(\mathrm{P}=\mathrm{SP}+$ bentonite)

13. Treatment No $6+1$ g. $\mathrm{H} \cdot \mathrm{A}(\mathrm{P}=\mathrm{SP}+\mathrm{HA})$

14. Treatment No $6+1 \mathrm{~g}$. bentonite $+1 \mathrm{~g}$. H.A $(\mathrm{P}=\mathrm{SP}+$ bentonite $+\mathrm{HA})$

* SP means super phosphate.

${ }^{*} \mathrm{RP}$ means rock phosphate.

$(P=R P)$ means the source of $P$ was rock phosphate.

After one week from applying the treatments, plants were harvested and separated to shoots and roots, washed with distilled water, dried at $70^{\circ} \mathrm{C}$, fresh and dry weight was recorded then kept for $\mathrm{P}$ analyses. The solution in the lower pots of all the treatments was filtered (using filter paper); completed to $500 \mathrm{ml}$ solution, the $\mathrm{pH}$ was measured with the glass electrode and then analyzed for soluble P(John, (1970).

\section{Statistical Analyses}

The experiment was designed in a completely randomized design and each treatment was replicated three times. Data were statistically analyzed by multiple factor analysis of variance with the Duncan's multiple range test $(5 \%$ level $)$, using MSTAT program. 


\section{RESULTS AND DISCUSSION}

After 30 days results illustrated in (Fig. 2, 3 and Table 2) showed that, in general, the highest $\mathrm{NaHCO}_{3}$ extractable $\mathrm{P}$ were given by the treatment of $\mathrm{SP}+$ bentonite + HA. The behavior of rock phosphates with the studied factors indicated slight solubilization as compared to the addition of $\mathrm{HA}$ or bentonite separately or together. The presence of relatively high soluble $\mathrm{Ca}^{2+}$ and low native humus beside the presence of relatively high $\mathrm{pH}$ value could be the reason for the limited solubility of the rock phosphate. However, the extractable $P$ from the rock phosphate + organic matter treatment increased compared to the control may be due to increasing $P$ mobilization.

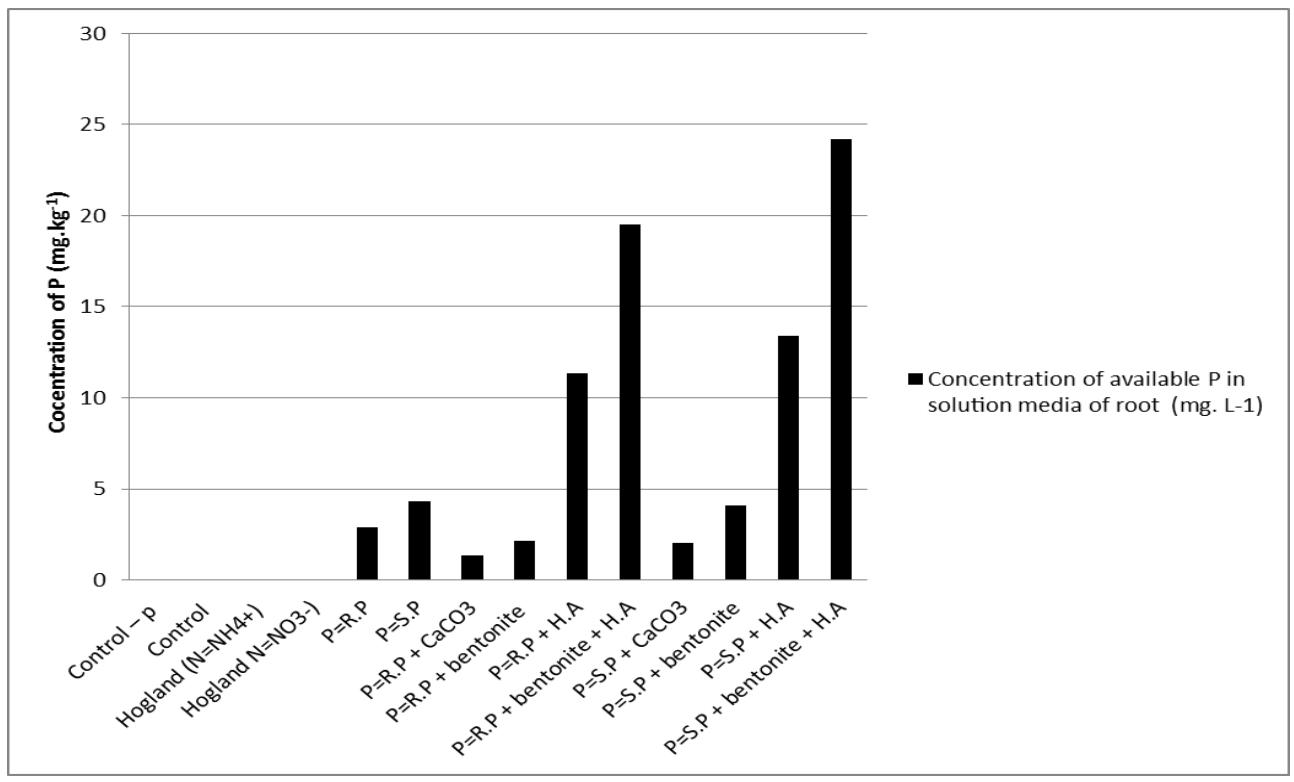

Fig. 2. Effect of $\mathrm{CaCO}_{3}, \mathrm{pH}, \mathrm{HA}$ and bentonite on availability of $\mathrm{P}$

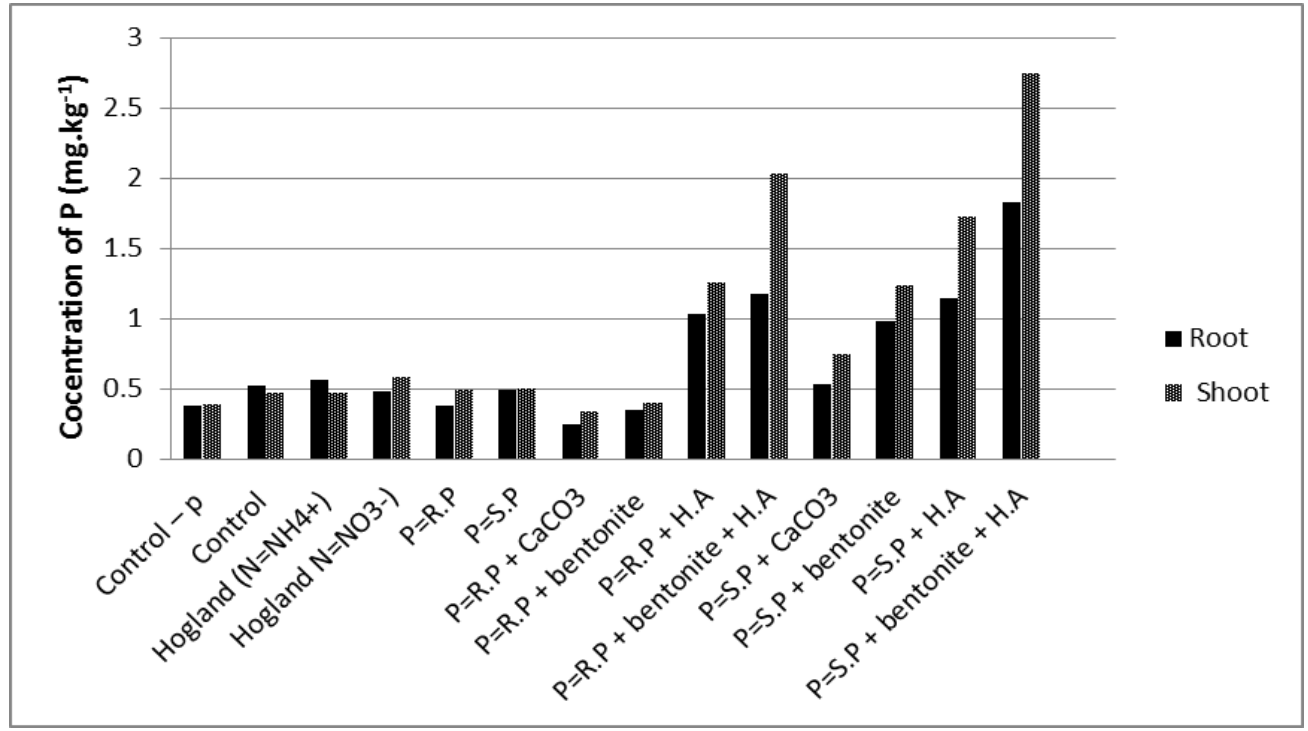

Fig.3. Effect of $\mathrm{CaCO} 3, \mathrm{pH}, \mathrm{HA}$ and bentonite on concentration of $\mathrm{P}$ in plant 
Table. 2. Effect of $\mathrm{CaCO}_{3}, \mathrm{pH}, \mathrm{HA}$ and bentonite on availability of $\mathrm{P}$

\begin{tabular}{|c|c|c|c|}
\hline \multirow[t]{2}{*}{ Treatments } & \multirow{2}{*}{$\begin{array}{l}\text { Concentration of } \\
\text { available } P \text { in } \\
\text { solution media } \\
\text { of root }\left(\mathrm{mg} . ~^{-1}\right)\end{array}$} & \multicolumn{2}{|c|}{ Concentration of $\mathrm{P}$ in plant $\left(\mathrm{mg} \cdot \mathrm{kg}^{-1}\right)$} \\
\hline & & Root & Shoot \\
\hline Control - p & $0.00100 \mathrm{~K}$ & $0.3760 \mathrm{~L}$ & $0.3940 \mathrm{M}$ \\
\hline Control & $0.001333 \mathrm{~K}$ & $0.5260 \mathrm{H}$ & $0.4763 \mathrm{~J}$ \\
\hline Hogland $\left(\mathrm{N}=\mathrm{NH}_{4}^{+}\right)$ & $0.0007333 \mathrm{~K}$ & $0.5610 \mathrm{~F}$ & $0.4700 \mathrm{~K}$ \\
\hline Hogland $\mathrm{N}=\mathrm{NO}_{3}^{-}$) & $0.001000 \mathrm{~K}$ & $0.4803 \mathrm{~J}$ & $0.5817 \mathrm{G}$ \\
\hline$P=R \cdot P$ & $2.900 \mathrm{G}$ & $0.3800 \mathrm{~K}$ & 0.4947 I \\
\hline$P=S . P$ & $4.326 \mathrm{E}$ & $0.4890 \mathrm{I}$ & $0.5003 \mathrm{H}$ \\
\hline $\mathrm{P}=\mathrm{R} \cdot \mathrm{P}+\mathrm{CaCO}_{3}$ & $1.376 \mathrm{~J}$ & $0.2520 \mathrm{~N}$ & $0.3360 \mathrm{~N}$ \\
\hline $\mathrm{P}=\mathrm{R} . \mathrm{P}+$ bentonite & $2.125 \mathrm{H}$ & $0.3500 \mathrm{M}$ & $0.4020 \mathrm{~L}$ \\
\hline$P=R \cdot P+H \cdot A$ & $11.32 \mathrm{D}$ & $1.029 \mathrm{D}$ & $1.255 \mathrm{D}$ \\
\hline $\mathrm{P}=\mathrm{R} . \mathrm{P}+$ bentonite $+\mathrm{H} . \mathrm{A}$ & $19.50 \mathrm{~B}$ & $1.176 \mathrm{~B}$ & $2.033 \mathrm{~B}$ \\
\hline $\mathrm{P}=\mathrm{S} \cdot \mathrm{P}+\mathrm{CaCO}_{3}$ & 2.0301 & $0.5313 \mathrm{G}$ & $0.7430 \mathrm{~F}$ \\
\hline $\mathrm{P}=\mathrm{S} . \mathrm{P}+$ bentonite & $4.080 \mathrm{~F}$ & $0.9783 \mathrm{E}$ & $1.235 \mathrm{E}$ \\
\hline$P=S \cdot P+H \cdot A$ & $13.41 \mathrm{C}$ & $1.144 \mathrm{C}$ & $1.728 \mathrm{C}$ \\
\hline $\mathrm{P}=\mathrm{S} . \mathrm{P}+$ bentonite $+\mathrm{H} . \mathrm{A}$ & $24.21 \mathrm{~A}$ & $1.831 \mathrm{~A}$ & 2.75 \\
\hline
\end{tabular}

. The same streak within factors are not different but $A$ value $>B>C$....etc. at the $5 \%$ level according to Duncan's multiple range test.

* SP means Super phosphate. $\quad$ * RP means Rock phosphate. (P=RP) means the source of $\mathrm{P}$ was Rock Phosphate.

The composting rock phosphate materials with straw or other organic waste materials resulted in phosphate mobilization. They further indicated that the driving force for rock phosphate solubilization is the $\mathrm{pH}$ decrease and the chelating effect of simple organic acids as citric and malic, and complex acids as humic and fulvic acids on $\mathrm{Ca}^{2+}$ ions from insoluble phosphate forms. Also, increasing available $P$ in soil by addition with these treatments reflected on increasing $P$ concentration in bean roots and shoots, with high concentrations in shoots more than roots (Amberger and Singh 1981, Amberger, 1991). Sahin et al (2014) reported that humic substances in interaction with $P$ in the soil could decrease the $P$ fixation and increase the $P$ uptake of plants. Humic acid served as a buffer at a broad $\mathrm{pH}$ interval and several macro and micro elements could be taken by the plants since the soil was neutralized.

Results illustrated in Fig. 4 and Table 3 indicated a decrease in the $\mathrm{pH}$ value of about 3-units in the solution when $\mathrm{NH}_{4}{ }^{+}$was used as a source of $\mathrm{N}$ in the nutrient solution, while there was an increase of about 0.2 -unit of the $\mathrm{pH}$ when $\mathrm{NO}_{3}^{-}$was the only $\mathrm{N}$-form added. Such phenomenon was reported by several investigators for leguminous and non-leguminous plants (Fisher et al 1989; Gahoonia and Nielsen, 1992 and Gahoonia et al 1992). It was further postulated that with $\mathrm{NH}_{4}^{+}$as $\mathrm{N}$ source more cations than anions were taken up to maintain an electrical charge balance and conse quently a net $\mathrm{H}^{+}$ion extrusion from the root occurred (Hoffland et al 1987).

The results found for bean plants showed also a drop in $\mathrm{pH}$ of about 2.4 units for $\mathrm{P}$ - deficient plants; it was reported that under certain stress conditions, roots, in order to overcome such phenomena exudates organic molecules as citric and malic acids (Hoffland et al $\mathbf{1 9 8 9}$ and Grieson, 1992), amino acids and reducing or chelating compounds (Amberger and Singh, 1981; Elgala and Amberger, 1988 and Grover, 2003).

On the other hand, results of $\mathrm{pH}$ value in the presence of plants show a pronounced increase as a result of root activity which reached to an increase of about 0.1 to 5 units in all $P$ treatments (Fisher et al 1989 and Gahoonia et al 1992b). It is worth to mention that more increase in $\mathrm{pH}$ was recorded with the low reactive source of $\mathrm{RP}+\mathrm{Ca}$ $\mathrm{CO}_{3}$, followed by the same $\mathrm{P}$ source with addition of HA. Bais et al (2006) divided root exudates into two classes of compounds. Low-molecular weight compounds such as amino acids, organic acids, sugars, phenolics, and other secondary metabolites account for much of the diversity of root exudates, whereas high molecular weight exudates, such as mucilage (polysaccharides) and proteins, were less diverse but often composed a larger proportion of the root exudates by mass. (El-Sherif et al 1976) reported that from the factors affecting $\mathrm{P}$-fixation in soils were $\mathrm{pH}$, clay minerals, $\mathrm{CaCO}_{3}$ content as well as soluble $\mathrm{Ca}$ in alkaline and soluble $\mathrm{Al}$ and $\mathrm{Fe}$ in acid soils. 


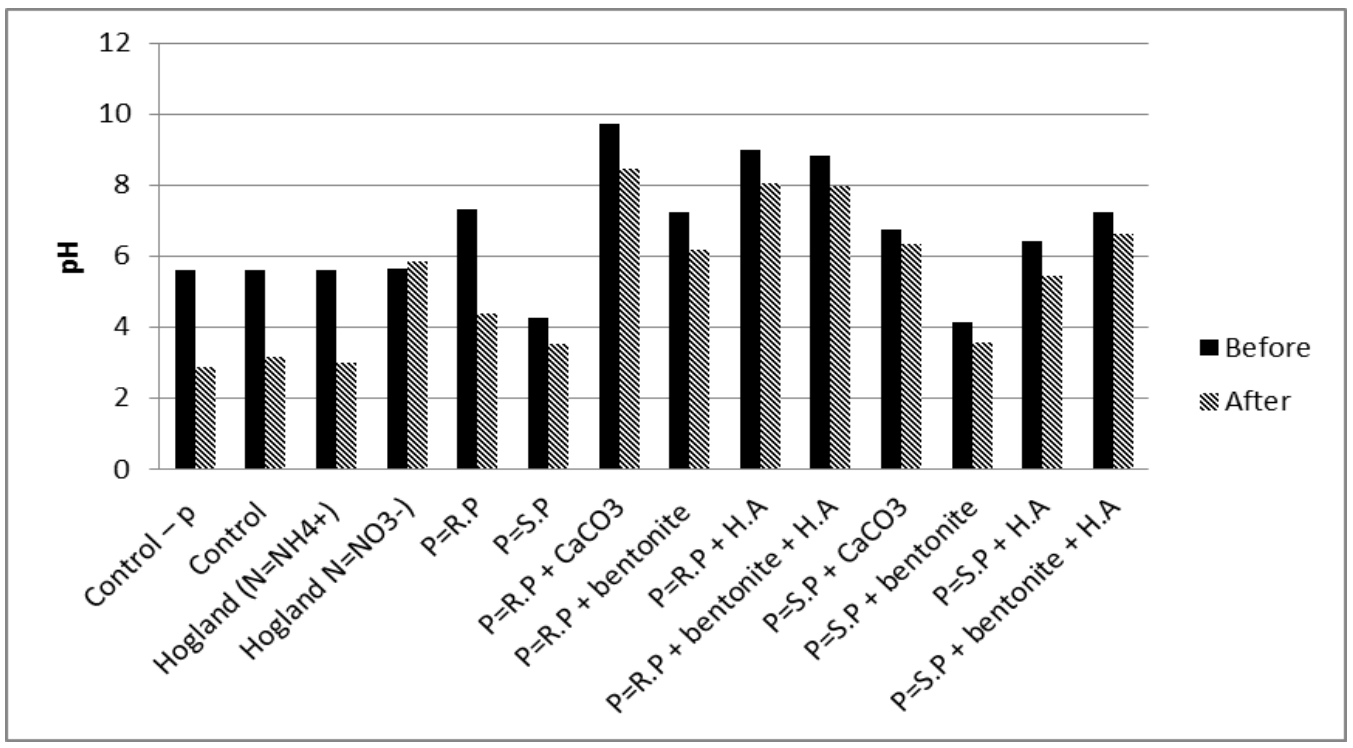

Fig. 4. Effect of $\mathrm{CaCO}_{3}, \mathrm{pH}, \mathrm{HA}$ and bentonite on $\mathrm{pH}$ of root's solution

Table .3. Effect of $\mathrm{CaCO}_{3}, \mathrm{pH}, \mathrm{HA}$ and bentonite on $\mathrm{pH}$ of media, fresh and dry weight (g.)

\begin{tabular}{|c|c|c|c|c|c|c|}
\hline & \multicolumn{2}{|c|}{$\begin{array}{c}\text { pH of solution media } \\
\text { of root }\end{array}$} & \multirow[t]{2}{*}{ Fresh root } & \multirow[t]{2}{*}{ Dry root } & \multirow{2}{*}{$\begin{array}{l}\text { Fresh } \\
\text { shoot }\end{array}$} & \multirow[t]{2}{*}{ Dry Shoot } \\
\hline & Before & After & & & & \\
\hline Control - p & $5.613 I$ & $2.867 \mathrm{M}$ & $1.113 \mathrm{C}$ & $0.2630 \mathrm{~N}$ & 3.813 EF & $0.5960 \mathrm{H}$ \\
\hline Control & 5.597 I & $3.167 \mathrm{~K}$ & $4.317 \mathrm{~A}$ & $0.4580 \mathrm{E}$ & $5.493 \mathrm{~B}$ & $0.7010 \mathrm{D}$ \\
\hline Hogland $\left(\mathrm{N}=\mathrm{NH}_{4}^{+}\right)$ & $5.620 \mathrm{HI}$ & $2.980 \mathrm{~L}$ & $1.403 \mathrm{C}$ & 0.3707 I & 4.220 DE & 0.5873 I \\
\hline Hogland $\mathrm{N}=\mathrm{NO}_{3}{ }^{-}$) & $5.650 \mathrm{H}$ & $5.823 \mathrm{G}$ & $4.577 \mathrm{~A}$ & $0.4500 \mathrm{~F}$ & $6.400 \mathrm{~A}$ & $0.8790 \mathrm{~A}$ \\
\hline $\mathrm{P}=\mathrm{R} \cdot \mathrm{P}$ & $7.330 \mathrm{D}$ & 4.367 I & $1.263 \mathrm{C}$ & $0.4000 \mathrm{H}$ & $4.583 \mathrm{CD}$ & $0.6960 \mathrm{DE}$ \\
\hline$P=S . P$ & $4.243 \mathrm{~J}$ & $3.530 \mathrm{~J}$ & $1.680 \mathrm{C}$ & $0.3103 \mathrm{M}$ & $3.697 \mathrm{~F}$ & $0.5930 \mathrm{H}$ \\
\hline $\mathrm{P}=\mathrm{R} \cdot \mathrm{P}+\mathrm{CaCO}_{3}$ & $9.737 \mathrm{~A}$ & $8.467 \mathrm{~A}$ & $4.873 \mathrm{~A}$ & $0.3267 \mathrm{~L}$ & $4.543 \mathrm{CD}$ & $0.5560 \mathrm{~J}$ \\
\hline $\mathrm{P}=\mathrm{R} . \mathrm{P}+$ bentonite & $7.237 \mathrm{E}$ & $6.167 \mathrm{~F}$ & $4.223 \mathrm{~A}$ & $0.3617 \mathrm{~J}$ & $5.480 \mathrm{~B}$ & $0.6330 \mathrm{G}$ \\
\hline$P=R \cdot P+H . A$ & $8.970 \mathrm{~B}$ & $8.027 \mathrm{~B}$ & $3.140 \mathrm{~B}$ & $0.4303 \mathrm{G}$ & $4.497 \mathrm{CD}$ & $0.7647 \mathrm{C}$ \\
\hline $\mathrm{P}=\mathrm{R} . \mathrm{P}+$ bentonite $+\mathrm{H} . \mathrm{A}$ & $8.837 \mathrm{C}$ & $7.960 \mathrm{C}$ & $4.017 \mathrm{AB}$ & $0.5003 \mathrm{~B}$ & $5.360 \mathrm{~B}$ & $0.8810 \mathrm{~A}$ \\
\hline $\mathrm{P}=\mathrm{S} \cdot \mathrm{P}+\mathrm{CaCO}_{3}$ & $6.753 \mathrm{~F}$ & $6.337 \mathrm{E}$ & $3.940 \mathrm{AB}$ & $0.4937 \mathrm{C}$ & $4.730 \mathrm{C}$ & $0.6940 \mathrm{E}$ \\
\hline $\mathrm{P}=\mathrm{S} . \mathrm{P}+$ bentonite & $4.120 \mathrm{~K}$ & $3.557 \mathrm{~J}$ & 3.297 B & $0.5467 \mathrm{~A}$ & $4.477 \mathrm{CD}$ & $0.8660 \mathrm{~B}$ \\
\hline$P=S . P+H . A$ & $6.420 \mathrm{G}$ & $5.423 \mathrm{H}$ & $4.717 \mathrm{~A}$ & $0.4780 \mathrm{D}$ & 5.697 B & $0.6770 \mathrm{~F}$ \\
\hline $\mathrm{P}=\mathrm{S} . \mathrm{P}+$ bentonite $+\mathrm{H} . \mathrm{A}$ & $7.240 \mathrm{E}$ & $6.610 \mathrm{D}$ & $3.193 \mathrm{~B}$ & $0.3320 \mathrm{~K}$ & $6.637 \mathrm{~A}$ & $0.6813 \mathrm{~F}$ \\
\hline
\end{tabular}

- The same streak within factors are not different but $A$ value $>B>C \ldots \ldots$.etc. at the $5 \%$ level according to Duncan's multiple range test.

* SP means Super phosphate

*RP means Rock phosphate.

(P=RP) means the source of $\mathrm{P}$ was Rock Phosphate. 
The fresh and dry weights of bean shoots shows relatively higher values when $\mathrm{NO}_{3}^{-}$the only form was supplied (Table 3 ). It is interesting to note that the root/shoot ratio was the highest for $\mathrm{P}$ deficient plants, Foehse and Jungk (1983) and Hoffland et al (1989) indicated that root growth and number of root hairs and length increased, also the amount of $\mathrm{H}^{+}$ion increased as plants became more $\mathrm{P}$-deficient.

Data of fresh and dry bean weights illustrated in Figs. 5 and 6 and Table 3 confirm the previous finding of the role of root exudates in mobilizing insoluble $\mathrm{P}$ sources and also the action of soil components as the fresh and dry weights of both shoots and roots remarkably increased with the lowest effect with RP when was applied alone. The highest fresh root weight was recorded by the treatment of $\mathrm{SP}+\mathrm{HA}$, the highest dry root weight was recorded by the treatment of SP + bentonite. While, the highest fresh shoot weight was recorded by the treatment of SP + bentonite + HA, the highest dry shoot weight was recorded by the treatment of RP + bentonite + HA.

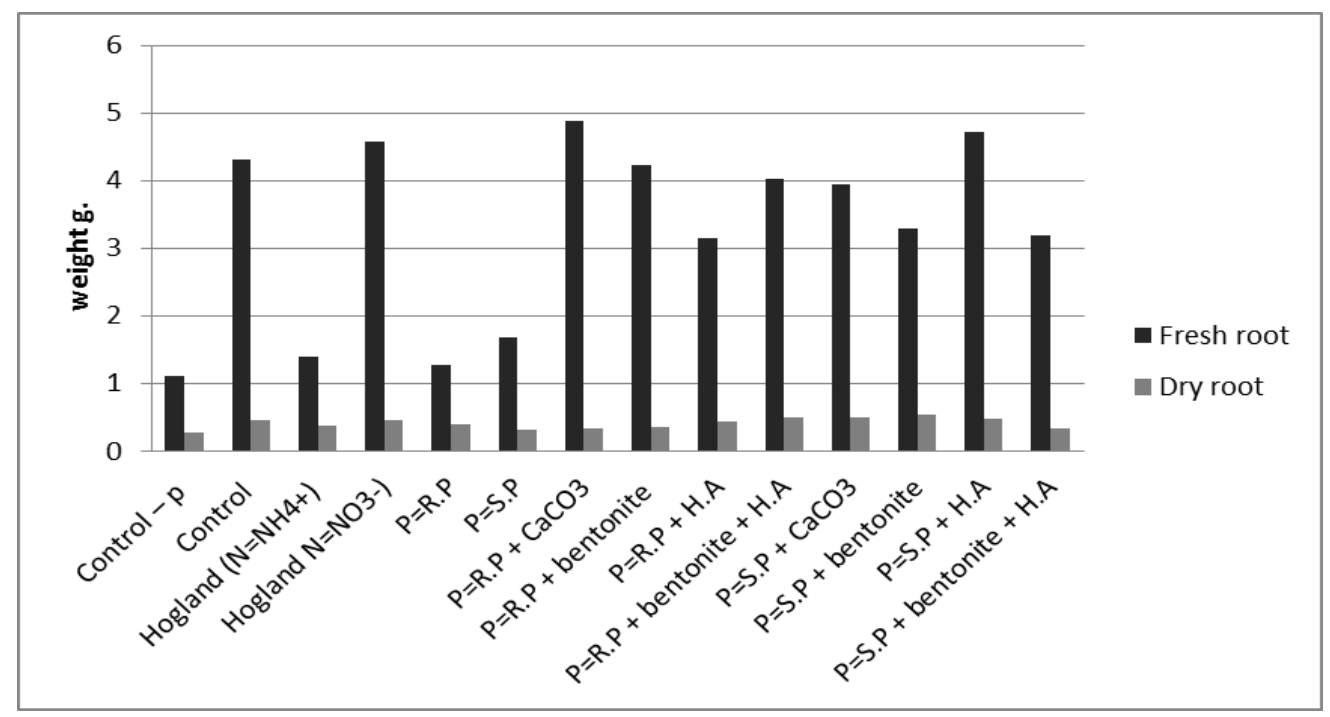

Fig. 5. Effect of $\mathrm{CaCO}_{3}, \mathrm{pH}, \mathrm{HA}$ and Bentonite on $\mathrm{pH}$ of fresh and dry weight for shoot (g.)

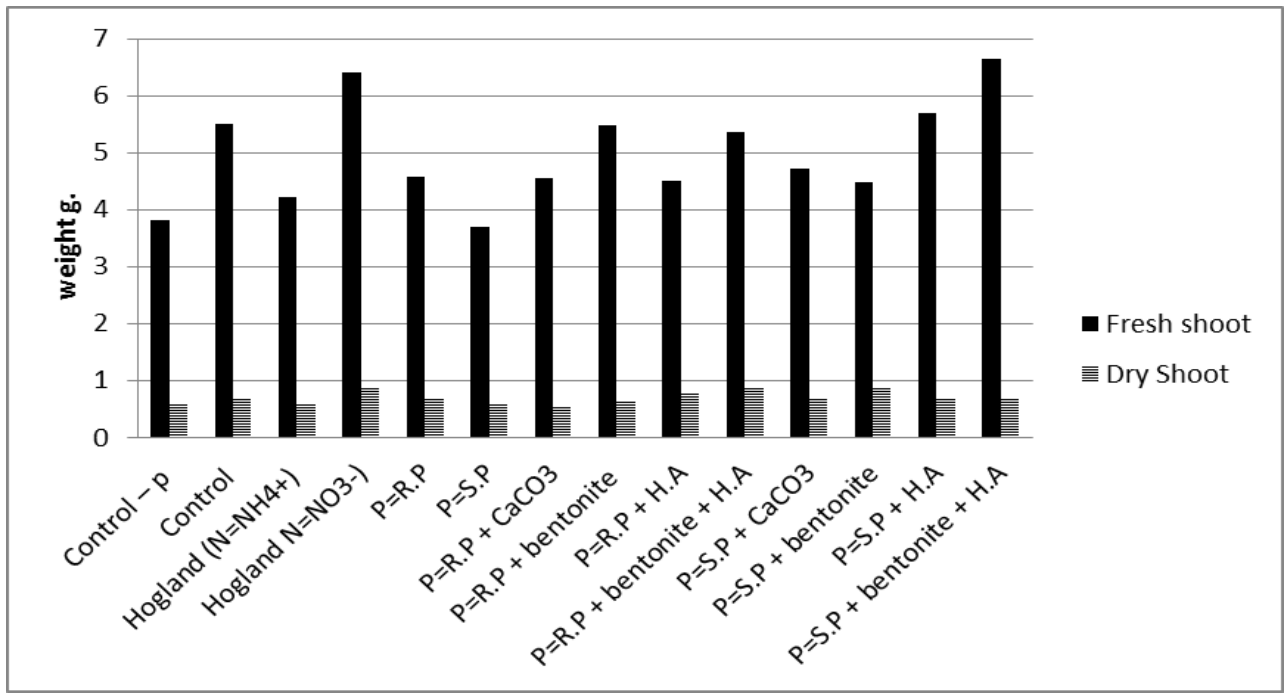

Fig. 6. Effect of $\mathrm{CaCO}_{3}, \mathrm{pH}, \mathrm{HA}$ and Bentonite on $\mathrm{pH}$ of fresh and dry weight for root (g.) 
Thus, it is clear that roots of bean plants were able to utilize insoluble sources of rock phosphate placed in solution but soil components interacted with solubilized $\mathrm{P}$ and hinder it unavailable to plants especially when $\mathrm{CaCO}_{3}$ was added. So the mechanism of solubilizing rock phosphate by exudating protons or organic, amino and other organic compounds is possible at the root surface even in alkaline soil as long as the rock phosphate material was added near the root and organic matter a combined with to limit the fixing power of the inorganic components as $\mathrm{CaCO}_{3}$ and excess soluble $\mathrm{Ca}$. Also, the availability of $\mathrm{P}$ from rock phosphate sources depends on its reactivity value. These results agreed with those reported by Bais et al (2006).

\section{CONCLUSIONS}

The factors affecting P-fixation in soils were $\mathrm{pH}$, clay minerals, $\mathrm{CaCO}_{3}$ content as well as soluble $\mathrm{Ca}$ in alkaline and soluble $\mathrm{Al}$ and $\mathrm{Fe}$ in acid soils. Rock phosphate can be used as a source of $P$ in alluvial and calcareous soils as long as organic matter is mixed close to the root system. the role of root exudates in mobilizing insoluble $P$ sources and also the action of soil components as the fresh and dry weights of both shoots and roots remarkably increased with the lowest effect with RP when was applied alone. Moreover, application of rock phosphate + organic matter treatment increased compared to the control may be due to increasing $\mathrm{P}$ mobilization. The result indicated that $\mathrm{SP}+$ bentonite treatment was the most effective to increases dry root weight. while, the highest dry shoot weight was recorded by the treatment of RP + bentonite + HA.

\section{REFERENCES}

Adani F., Genevini P., Zaccheo P. and Zocchi G. 1998. The effect of commercial humic acid on tomato plant growth and mineral nutrition. J. Plant Nutrition., 21, 561-575.

Afif E., Matar A. and Torrent J. 1993. Availability of phosphate applied to calcareous soils of West Asia and North Africa. Soil Sci. Society of America J. 57, 756-760.

Amberger, A.; Singh, CP. 1981. Effect of humic substances on solubilization of rock phosphate incubated with wheat straw. J. Plant Nutrition., 3(1-4), 579-591.
Amberger A.1991. Mobilization of rock phosphate in soils. $2^{\text {nd }}$ ASSS conf., Soil and Water Management of Sustainable Productivity by A.M. Elgala, et al Cairo, Egypt, pp. 63-70.

Bais H.P., Weir T.L., Perry L.G., Gilroy S. and Vivanco J.M. 2006. The role of root exudates in rhizosphere interactions with plants and other organisms. Annul Rev. Plant Biol., 57, 233-266.

Carreira J.A. and Lajtha K.L. 1997. Factors affecting phosphate sorption along a Mediterranean dolomite soil and vegetation chronosequence. European J. of Soil Sci., 48, 139149.

Cenellas L.P., Olivares F.L., OkorokovaFacanha. A.L. and Facanha A.R. 2002. Humic acids isolated from earthworm compost enhance root elon- gation, lateral root emergence and plasma membrane H-ATPase activity in maize roots. Plant Physiology, 130, 19511957.

Chen Y., Clapp C.E. and Magen H. 2004. Mechanisms of plant growth stimulation by humic substances: The role of organic-iron complexes. Soil Sci. and Plant Nutrition, 50, 10891095.

Delgado A., Madrid A., Kassem S., Andreu L. and Campillo M. 2002. Phosphorus fertilizer recovery from calcareous soils amended with humic and fulvic acids. Plant and Soil 245, 277-286.

Doran I., Akinci C. and Yildirim M. 2003. Effects of delta humate applied with different doses and methods on yield and yield components of diyarbakir-81 wheat cultivar. $5^{\text {th }}$ Field Crops Congress. Diyarbakir. Turkey. 2, 530-534.

Elgala A.M. and Amberger A. 1988. Root exudate and the ability of corn to utilize insoluble sources of iron. J. Plant Nutrition. 11(6-11), 677-690.

El-Sherif A.F., Elgala A.M. and El-leboudi A. 1976. Studies on the phosphorus availability under saline and alkali soil conditions. The Int. Symp.on Salt Affected Soils, Cairo, Egypt. pp. 4-9.

Fisher R.W., Heiner F. and Schaller G. 1989. pH values and redox potentials in microsites of the rhizosphere. Z. PIflanzenernăhr. Bondenk. 152, 191-195.

Foehse D. and Jungk A. 1983. Influence of phosphate and nitrate supply on root hairformation of rape, spinach and tomato plants. Plant and Soil. 74, 359-368. 
Gahoonia T.S. and Nilesen N.E. 1992a. The effect of root induced change on the depletion of inorganic and organic phosphorus in the rhizosphere. Plant and Soil 143, 185-191.

Gahoonia T.S., Classen N. and Jungk A. 1992b. Mobilization of phosphate in different Soils by ryegrass supplied with ammonium or nitrate. Plant and Soil 140, 241-248.

Giesler R., Andersson T., Lövgren L. and Persson P. 2005. Phosphate sorption in alumium- and iron-rich humus soils. Soil Sci. Society of America J. 69, 77-86.

Grieseon P.E. 1992. Organic acids in the rhizosphere of Baksia intergrifolia L. Plant and Soil 144, 259-265.

GrossI P.R. and Inskeep W.P. 1991. Precipitation of dicalcium phosphate dihydrate in the presence of organic acids. Soil Sci. Soc. Am. J. $55,670-675$.

Grover R. 2003. Rock phosphate and phosphate solubilizing microbes as a source of nutrients for crops. M.Sc. Thesis, Patiala;

Hoffland E., Findenegg G.R. and Nelemans J.A. 1989. Solubilization of rock phosphate by rape local root exudation of organic acids as a response of P-starvation. Plant and Soil 113, 155-161.

Hopkins B. and Ellsworth J. 2005. Phosphorus availability with alkaline /calcareous soil. Western Nutrient Management Conference. V6. Salt Lake City, UT.

Jenkins, T.A. and Jenkins V. 2012. The future of phosphorus in agriculture and the environment. The 1stInternational Congress of Ecologists, University of Business Studies, Banja Luka, Bosnia and Herzegovina. pp. 1481-1497.
Kaiser K. and Zech W. 1997. Competitive sorption of dissolved organic matter fractions to soil and related mineral phases. Sci. Society of America J. 61, 64-69.

Mackowiak C.L., GrossI P.R. and Bugbee B.G. 2001. Beneficial Effects of Humic Acid on Micronutrient Availability to Wheat. Soil Sci. Soc. Am. J. 65, 1744-1750.

Robbins C.W., Westermann D.T. and Freeborn L.L. 1999. Phosphorus forms, extractability, and availability from three sources in a recently exposed calcareous subsoil. Soil Sci. Society of America J. 63, 1717-1724.

Sahin S., Karaman M.R. and Gebologlu N. 2014. The effect of humic acid application upon the phosphorus uptake of the tomato plant (Lycopersicum esculentum L.). Sci. Res. Essay., 9, 586-590.

Satisha G. and Devarajan L. 2005. Humic substances and their complexation with phosphorus and calcium during composting of pressmud and other biodegradables. Communications in Soil Sci. and Plant Analysis 36, 805-818.

Tunesi S., Poggi V. and Gessa C.1999. Phosphate adsorption and precipitation in calcareous soils: the role of calcium ions in solution and carbonate minerals. Nutrient Cycling in Agroecosystems. 53, 219-227.

Zhou M. and Li Y. 2001. Phosphorus-sorption characteristics of calcareous soils and limestone from the Southern Everglades and adjacent farmlands. Soil Sci. Society of America J. 65, 1404-1412. 
المؤتمر الرابع عشر لبحوث التنمية الزراعية،

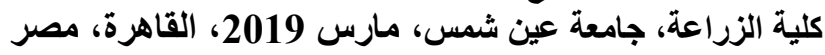

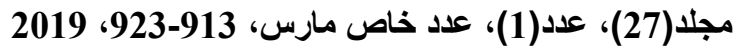
Website: http://strategy-plan.asu.edu.eg/AUJASCl/

دراسة على بعض العوامل المؤثرة على تيسر الفوسفور فى منطقة الريزوسفير

[84]

رقية صلاح الحاج"- عبد المنعم محمد الجلا - محمد على عثمان الشعراوى - محد عبد الفتاح عيد

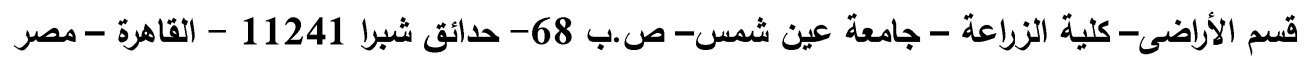

*Corresponding author: rookaia_salah@agr.asu.edu.eg

Received 1 October, $2018 \quad$ Accepted 9 October, 2018

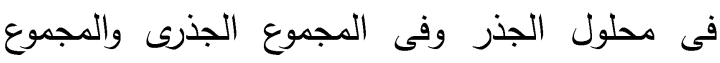

الخضرى و كذالك الوزن الطازج والجاف لكلاهما.

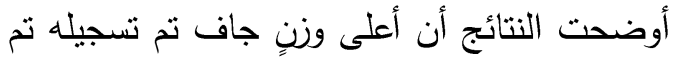
العثور عليه عندما تم تطبيق كلا من الأشكال N في

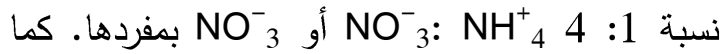
تظهر النتائج أن درجة تيسر الفوسفور كانت أعلى فى وجود المادة العضويه مع البنتونيت والسوبر فوسفات ثم ثئر المادة العضويه مع البنتونيت وصخر الفوسفات تليها المادة العضويه مع صخر الفوسفور بشرط وضع وليه المعاملات فى الطبقة السطحيه جوار منطقة إنتشار الجذور حيث وجد أن إفرازات الجذور لها تأثير مؤثر على تيسر الفوسفور للنبات وزيادة معدلاته.

الكلمات الدالة: المادة العضوية،البنتونيت، كربونات

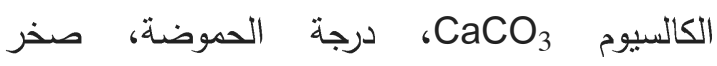
الفوسفات، منطقة الريزوسفير، تقنية الوسط المنقسم،

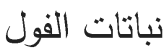

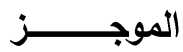

تهدف هذه الدراسة إلى دراسة تأثثر بعض العوامل

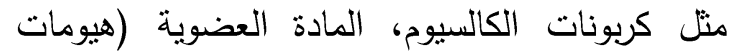

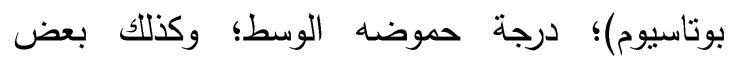

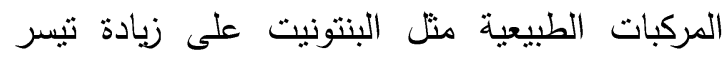
الفوسفور للنبات بإستخدام صخر الفوسفات وسماد الفئي السوبر فوسفات الثثلثى وتقدير الكمية الميسرة منهما وتركيزهما فى النبات تحت الدراسة. وعلى هذا تم إجراء تجربة الوسط النيات المنقسم وكان الهدف منها دراسة تأثير المعاملات المختلفة على زيادة التهات

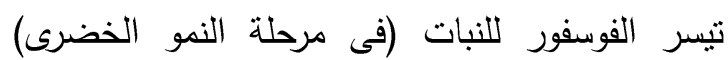
تحت تأثير إفرازات الجذور وتأثير العوامل محل النول الدراسة. تم تسجيل التغيرات في الرقم الهيدروجيني لمحلول الجذور السفلي، كما تم قياس تركيز الفوسفور الميسر 